\title{
Under Review: Nordic Literature of Decadence. Edited by Pirjo Lyytikäinen, Riikka Rossi, Viola Parente-Čapková, and Mirjam Hinrikus (London and New York: Routledge, 2020)
}

\author{
Ian Gwin
}

DOI: https://doi.org/10.7592/methis.v22i27/28.18452

Keywords: decadence, Nordic literature, philosophy, modernism, Young Estonia

“I do not yet fully understand what I have read... But I find much that harmonizes with my own ideas and sympathies," the Danish scholar Georg Brandes wrote to the philosopher Friedrich Nietzsche in November of 1887 after receiving his book Beyond Good and Evil, in the mail, "the depreciation of the ascetic ideals and the profound disgust with democratic mediocrity, your aristocratic radicalism. Your contempt for the morality of pity is not yet clear to me. There were also in the other work some reflections on women in general which did not agree with my own line of thought." Approving of Brandes' term, "aristocratic radicalism," Nietzsche wrote back that December, praising this term as "the cleverest thing I have yet to read about myself" (Brandes 1914, 63-64).

The discussion that followed between the two writers over modernity, "this paramount problem of values," as Nietzsche described it in a letter one year later (Brandes 1914, 71), touches on key themes of the fin de siècle which found expression in a style of art and literature known as decadence. A certain proximity to death, illnesses of mind, body, and spirit, not to mention the problem of European culture, bore the marks of the overall decline (la décadence) of an industrialized society championing positivist science and inevitable moral progress. This disgust with life, "life turned against life," as Brandes wrote, produced aristocratic radicals such as Des Esseintes, the hero of Joris Husymans' 1884 novel $\dot{A}$ Rebours, who retreats to a house in the country and pursues a secluded life of aesthetic pleasure and hedonist excess (Brandes 1914, 41).

In their recent addition to the Routledge's series Among the Victorians the Modernists, scholars Pirjo Lyytikäinen, Riikka Rossi, Viola Parente-Čapková, and Mirjam Hinrikus have provided a comprehensive introduction to this movement as it occurred in Denmark, Finland, Iceland, Norway, Sweden, and Estonia. Brandes' early reception of Nietzsche demonstrates the sensitivity of Nordic authors living under a dark northern sky "no longer lit by the consoling beacons of the ancient hope," as Des Esseintes cries out before returning to Paris (Huysmans 2008, 236). 
In fact, as contributor Lis Norup points out, novels like J. P. Jacobsen's Niels Lyhne and Herman Bang's Haabløse Slagter, both written in 1880, actually predate Huysmans' prototypical caricature of decadence and his overcoming of the naturalist style (Lyytikäinen et al. 2020, 41).

Previous works on international decadence, notably George C. Schoolfield's A Baedeker of Decadence (2003) and Marja Härmänmaa's and Christopher Nissen's recent Decadence, Degeneration, and the End: Studies in the European Fin de Siècle (2014), have also sought to describe harmonies and sympathies between Northern literatures and the places where decadence got its name. Yet until now, no introductory volume has been devoted to a comparative study throughout the Nordic region. Schoolfield did, however write his work in partial response to the shortcomings of Rafael Koskimies' Der nordische Dekadent (1968). While writing on Per Thomas Andersen's Dekadanse i nordisk litteratur 1880-1900 (1992), he noted significant writers and problems ignored by either author. The question remained, for example, as to why features of mainstream European decadence were underrepresented or even absent in North Europe, such as self-parody, or the paradigm of Roman history (Schoolfield 1997, 248). Schoolfield's well-researched global history of the motifs and fixations of the era mentions August Strindberg, Arne Garborg, Karl August Tavastjerna, Oscar Levertin, Gustaf af Geijerstam, Hjalmar Söderberg, Kjell Strömberg, Herman Bang, and Halldór Laxness, yet leaves out important contributors like Ola Hansson, who, despite being driven into exile for his Sensitiva Amorosa (1887), had an effect within the Nordic region on writers such as Volter Kilpi (Lyytikäinen et al. 2020, 9). Unlike Schoolfield, who presents a series of samples or profiles to tackle the era's sensibility, Lyytikäinen et al. have co-authored an overview of the field and its history, complemented by contributions from regional scholars and specialists in other disciplines, grouped according to relations with European decadence, rural decadence, women writers, incipient modernism, and representations of the North in European decadence.

The authors of the volume conceive this virulent spreading over Europe as a constellation of primarily French influence, one that deploys the images of cultural, social, and individual decay, taking root in different grounds and climates. For them, decadence consists of a constellation of themes - an interest in decay, a reaction to modernity, and a sense of an ending - which characterized various 19th century movements between romanticism and modernism (Weir 1995, xvii).

This constellation takes shape in three notable ways, beginning with a modification of naturalism. The pessimistic view on the decline of culture, creative energy, personal morality, which Vincent Sherry (2015) argues becomes a key theme of modernism, inspired a peculiar modification and even distortion of literary natural- 
ism, which can be found in authors like Jacobsen and Bang. Following this "decadent naturalism" - which had been the partial impetus for Huysmans writing of $\dot{A}$ Rebours - the authors describe a "core decadence" which corresponds with the cannon as outlined in previous literature on the subject. Finally, the themes, methods, and preoccupations of decadence extend past this period of works into modernity's decadent "afterlife," as the authors argue persuasively in their afterword.

"Your nature is so absolutely different from mine that it is not easy for me to feel at home," Brandes cautions Nietzsche in their correspondence (Brandes 1914, 63). The Danes' uneasy relation to the German philosopher's extreme politics, his attitudes on women, even his admonition to read the Icelandic sagas, mark the notable peculiarities of Nordic decadences. These motifs, not to mention Nietzsche's reception in the region, could be interpreted more in line with established literary histories which avoid an encompassing "decadence," and its possible implications of shared intentions among authors. Yet in line with other scholars of the "New Decadence," the authors of the present volume are less interested in categorization and classification than in thinking of forms and techniques of modernist aesthetics as they circulate globally (Volpicelli 2019, 218).

When interpreted as a received sensibility, Nordic decadence becomes subject to the "lag and noise" of cultural transfer from well-developed metropoles like Paris or St. Petersburg to largely rural nations developing on alternate political and economic trajectories. Here, Lyytikäinen et al. make their core contributions to decadence at large and in the Nordic region by challenging terms typical of the national literary discourse such as "modern breakthrough," "neo-romanticism," and "national romanticism," in describing these separate features of Nordic decadence.

These observations proceed from an excellent handling of historical, linguistic, and geographic nuance, which extends throughout the volume. While Brandes could write from a country well connected to Western and Central European cultural life, authors like the Estonian Gustav Suits depended on the former's lectures to hear about Nietzsche and the rest of central Europe literary goings-on. The relatively separate cultural life of Sweden and Norway - not to mention Finland and Estonia's late independence from the Russian Empire - are key to understanding literary developments at the time (Lyytikäinen et al. 2020, 7). The nationalist literary heritage of the Nordic regions, which the authors describe as a fusion of folk-poetry and neo-humanist ideals, held the Nordic decadents in antagonistic dialogue. These authors, marginalized in national literary histories, contended with a Lutheran church closely connected to the state and a developing democracy where women's social roles were changing dramatically. 
Thus the Bovarists of J. P. Jacobsen or Juhani Aho, while also aesthetes and dandies immersed in their own fantasies, are implicated in historical and national indeterminacies, as well as varieties of pessimism, vastly different from Des Esseintes. These young, egocentric, "weary men" - to borrow the title of Garborg's 1891 novel Trætte Mænd - are less taken with exoticism and artificiality due precisely to their connection with rural life. While a provincial milieu and natural scenery characterize Huysmans' works following Á Rebours, Lyytikäinen et al. answer Schoolfield's question by proposing a subgenre particular to the region, rural decadence. Following Emile Zola's epic of a decaying agricultural family La Terre, they note the idealization of peasants and rural life as key parts of the Nordic national imaginary, taken over and ultimately challenged by naturalist writers.

For their thematic section on rural decadence, these scholars take on the work of Finnish novelists Joel Lehtonen and Frans Eemil Sillanpää, arguing that these authors elaborated a transgressive poetics from Nordic environments, emotions, and spirituality. Lyytikäinen tackles the contradictory emotions towards nature in Joel Lehtonen's Mataleena, while Antti Ahmala follows with a discussion of another novel, Villi, which transposes French Bovarism into rural setting. Rossi finishes this section with a focus on primitivism and spirituality in Sillanpää's work, noting how the epigones of naturalism - the physical and organic world - become the vitalist source of spiritual truth to dispute fin de siècle positivism and rationality.

The authors' reconsideration and extension of decadence away from its core texts encourage reevaluations such as these. Considering the "alignment of pessimism and misogyny" in decadent texts, the book's section on women writers begins to address an important blind spot for scholarship (Weir 1995, xiv). In her article, Parente-Čapková discusses how L. Onerva's Mirdja (1908) reveals the gendered nature of urbanization in the region, and the relationship of natural spaces to national ideology. The Norwegian writer Dagny Juel Przybyszewska, now going through a small revival, receives some well-deserved attention in an article by Anne Birgitte Rønning. Like Parente-Čapková, Rønning notes the important contribution of women of the period to themes of cultural degeneration and natural decay. In contrast to her husband Stanistaw Przybyszewski, who made "constant use of his own sexual obsessions," Przybyszewska touches on yearnings of lust and death while surpassing a common masculine bias (Schoolfield 2003, 121).

The volume's other sections also emphasize the potential of understanding decadence anew from a Nordic vantage point. Writing on Nordic and European decadences, Lis Norup, Susan Brantly, and Guri Ellen Barstad analyse exemplary Danish, Swedish, and Norwegian texts as influential and representative of the sensibility's religious preoccupations and literary revitalization. Scholars of European 
decadence would do well to compare these essays with Stefano Evangelista, Melanie Hawthorne, and Juliet Simpson's chapters intertwining the regional movements with Europe. In her article, "Nordic Devotions: Gothic Art as Erotic Affect," Simpson makes the important observation that Huysmans' interest in Northern Gothic art provided the writer a portal to the excessive emotion of an imagined primitive, and thus the emerging reality of an "unseen modernity" (Lyytikäinen et al. 2020, 250).

It's not surprising, then, how important the concept of modernity is in both these individual contributions and in the authors' afterword. In their chapters devoted to Nordic decadence's challenges to modernity, Claes Ahlund and Mirjam Hinrikus respond by bringing up the important question of nationalism in the Nordic strain. Writing on Estonian decadence, Hinrikus notes the critiques and self-critique of the Young Estonian movement, who sought to run with the newest urban literary trends but had to reckon with the ideology of a young, largely rural nation. In his 1915 novel Felix Ormusson, Friedebert Tuglas depicts an aristocratic radical ironically at odds with his host Johannes, an urban upstart nevertheless close to his pastoral roots. While affected by European philosophies on race and social Darwinism, Tuglas reharmonizes these decadent themes and oppositions with a setting that challenges and even overrides them (Hinrikus in Lyytikäinen et al. 2020, 186).

These arguments indicate the authors' larger contribution to the critical literature on modernism: for them, the decadents represent neglected yet continually relevant aspects of modernity. In their insistence on "questioning the human subject, the revaluation of old values, and the turmoil around genders," they presented ambivalent reactions to the social changes of modernization - the common ground between Brandes and Nietzsche (Lyytikäinen et al. 2020, 266). Starting off with the tools of naturalism, where decadents hoped to depict the trappings of modern life, they ended up focusing on their world's negativity and boredom, reacting what Lyytikäinen et al. describe as antimodernism. Knut Hamsun's Slut gives one example of a work which begins in tragic naturalism and speeds forward through contradiction and transgression.

Opposed to this disgust at modern life, artists found themselves drawn towards a romanticized primitive, an ambivalent nostalgia for the natural and primordial (Lyytikäinen et al. 2020, 261). Here, the unique legacy of rural decadence comes into play, and the authors note the corruption, decay, and death in the epics of writers like Lehtonen and A. H. Tammsaare. The former's contradictory images of savage animality, combined with ideas of innocence and originality, and the latter's ambiguous depictions of empowered women, read with a sense of the negative primitive, well demonstrate this. Both of these troubling symptoms, antimodernism and the 
ambivalent primitive, make up the "continuity of sensibilities and themes" connecting 19 th century naturalism and 20 th century neo-naturalism within core decadence as it mingles and competes with high modernism (Lyytikäinen et al. 2020, 259).

The heritage, or afterlife, of decadence in the Nordic countries picks up some salient points on themes of doom, decay, and decline in the literary movements which followed after. Lyytikäinen et al. touch on the Finnish Tulenkantajat (Torch Bearers), and the Estonian proto-modernist group Siuru lincluding former Young Estonians Tuglas and Suits), experimental movements both overlooked in the English language. The recycling of decadent imagery, without the matching aesthetic or philosophical ambition, into works such as that of the late Strindberg, take part in what the authors call, after David Weir, the "decline of decadence," a paradoxical phrasing which brings into question both the decadent's timely "sense of an ending," and their subsequent passing out of (and back intol literary fashion.

Overall, the combined scholarship and expertise of its various contributors have made Nordic Literature of Decadence the comprehensive introduction to the subfield, not to mention an important contribution to studies of modernism and international decadence. There certainly remains more to be researched in the field, especially considering the volume focuses almost exclusively on works of prose. Work by scholars such as Kirsten Lodge, a specialist in Czech decadence, show how poetry could convey the themes of decline and decay modulated by a linguistic and regional reception, in what she describes as a uniquely Czech decadence of hunger, rather than satiation (Karásek ze Lvovic et al. 2008, 18). Notably absent, as well, are the works of fin de siècle authors elsewhere in the Baltic region, such as the poet Zemgaliešu Biruta, or the prolific Viktors Eglītis, whose work has been touched on in recent Latvian scholarship (Kalnačs et al. 2017). Perhaps the contours of the peculiar late modernism presented in decadent literature could be better understood if seen in geographic and historical relief with related national literatures. Or so it seems to the aristocratic androgyne Ruth, as imagined by the Estonian Juhan Randvere: "Tired of the salons and boudoirs" of French literature, she turns her back on them with an "unexplainable longing for home, towards the birch forests which Finnish and Estonian literature remind her of, so she can purify and refresh her soul in their gentle and homey green." (Randvere 1909, 34).

\section{Acknowledgments}

The author would like to thank Raili Marling for her helpful questions and comments on early versions of the following review. 


\section{Ref ere n c e s}

Andersen, Per Thomas. 1990. Dekadanse i Nordisk Litteratur 1880-1900. Oslo: Aschehoug.

Brandes, Georg, 1914. Friedrich Nietzsche. Translated by A. G. Chater. London: W. Heinemann.

Huysmans, Joris-Karl. 2008. Against Nature (À Rebours). Translated by Brendan King. Sawtry: Dedalus.

Härmänmaa, Marja, and Christopher Nissen. 2014. Decadence, Degeneration, and the End: Studies in the European Fin de Siècle. New York: Palgrave Macmillan.

Kalnačs, Benedikts, Pauls Daija, Eva Eglāja-Kristsone, and Kārlis Vērdinṇš. 2017. Fin de Siècle: Literārā Kultūra Latvijā: Apceres Par Literatūras Sociālo Vēsturi. Rīga: LFMI.

Karásek ze Lvovic, Jiří, Karel Hlaváček, Otokar Březina, and Kirsten Lodge. 2008. Solitude, Vanity, Night: An Anthology of Czech Decadent Poetry. Praha: Univerzita Karlova.

Koskimies, Rafael. 1968. Der Nordische Dekadent. Eine Vergleichende Literaturstudie. Helsinki: Suomalainen Tiedeakatemia.

Lyytikäinen, Pirjo, Riikka Rossi, Viola Parente-Čapková, and Mirjam Hinrikus, eds. 2020. Nordic Literature of Decadence. New York: Routledge.

Randvere, Juhan. 1909. "Ruth.” In Noor Eesti IIl Album. Author's Unpublished Translation. https:// www.kirmus.ee/nooreesti/noor-eesti-albumid/noor-eesti-iii-album/\#lk3-12.

Sherry, Vincent B. 2015. Modernism and the Reinvention of Decadence. New York: Cambridge University Press.

Schoolfield, George C. 1997. “Dekadanse i Nordisk Litteratur 1880-1900.” Scandinavian Studies 69 (2): 243-49.

Schoolfield, George C. 2003. A Baedeker of Decadence: Charting a Literary Fashion, 1884-1927. New Haven: Yale University Press.

Volpicelli, Robert. 2019. “The New Decadence." Modernism/modernity 26 (1): 213-18. https://doi. org/10.1353/mod.2019.0009.

Weir, David. 1995. Decadence and the Making of Modernism. Amherst: University of Massachusetts Press.

Ian Gwin - a writer and translator from Seattle, Washington. He holds a BA in linguistics and is currently pursuing his masters in Scandinavian Languages and Literatures at the University of Washington. He is currently translating work by the Young Estonian author Jaan Oks, as well as the contemporary Latvian writer Andris Kuprišs. e-mail: iangwin[at]uw.edu

Ian Gwin - kirjanik ja tõlkija Seattle'ist, Washingtoni osariigist. Tal on bakalaureusekraad lingvistikas ja ta õpib Washingtoni Ülikooli Skandinaavia keelte ja kirjanduste magistriõppekaval. Gwin tõlgib praegu NoorEesti autori Jaan Oksa ja nüüdisaegse Läti kirjaniku Andris Kuprišsi teoseid. e-post: iangwin[at]uw.edu 